\title{
Formation, expansion and restoration of a sedimentation fan: the case of the Arroyo del Partido stream (Spain)
}

\author{
J. A. Mintegui Aguirre ${ }^{1}$, J. C. Robredo Sánchez ${ }^{1}$, L. Mao ${ }^{2}$ \\ \& M. A. Lenzi ${ }^{3}$ \\ ${ }^{I}$ ETSI Montes, Universidad Politécnica de Madrid, Spain \\ ${ }^{2}$ Department of Geography, University of Hull, UK \\ ${ }^{3}$ Dipartimento Territorio e Sistemi Agro-Forestali, \\ Università di Padova, Italy
}

\begin{abstract}
The Arroyo del Partido is a small stream flowing into the Doñana National Park marsh. In its lower part, the stream used to flow in a wide, low-gradient area, where the channel was highly dynamic with frequent avulsions. As a result of a channel rectification, the subsequent floods heavily eroded the artificial banks and created over time a depositional fan within the Doñana marsh. The bedload dynamic at the annual scale was estimated from the expansion of the sedimentation fan, assessed from aerial photographs analysis and repetitive topographic surveys. The bedload transport ranged from $3.7 \times 10^{6}$ to $2.1 \times 10^{3} \mathrm{~m}^{3}$ per year, depending on the sequences of occurring floods and on the changing geometrical conditions of the main channel. The progressive erosion of the artificial banks led to self-established cross-sections and slope geometry, which reduced shear stress acting on the bed and favoured sediment deposition on the floodplains, reducing overtime the expansion of the sedimentation fan. This evidence has been used to plan a restoration strategy for the fan and floodplains, aimed to mitigate the effect of the embankment and to improve the overall functionality of the stream. As a result of the restoration, an artificial levee was eliminated and a wide floodplain area was recreated as a free-meandering floodplain.
\end{abstract}

Keywords: channel rectification, sedimentation fan, sediment transport, aerial photographs, topographical surveys, channel restoration. 


\section{Introduction}

The morphology and the dynamics of an alluvial river channel are the consequence of transport/deposition of sediments in the river bed. The component of the sediments transported mostly in contact with the bed is called bedload, and is the portion of the total sediment load that determines channel morphology. An accurate estimation of sediment transport is thus important for the prediction of channel morphological changes as well as to the success of a variety of river engineering and management practices such as channel design, river regulation, and in-stream construction. Bedload transport formulas are usually calibrated on laboratory data or on a limited amount of observations on specific study rivers, reducing the chances of their reliable application to a certain field site. Bedload formulas often overestimate sediment transport rates by one or more orders of magnitude, and sediment rates are accurately predicted only under unlimited sediment availability and supply conditions [4]. On the other hand, direct measurements of bedload transport requires a considerable field effort and are difficult to be conducted especially during floods, even if recent efforts have been made in developing and testing advanced field methods for the direct and indirect quantification of bedload transport [e.g. 1, 10, 19]. Additionally, representative measurements are difficult to obtain due to the significant spatial and temporal variability associated with bedload movement [6]. As an alternative, the rate of bedload transport can be evaluated at the single flood or at longer time scales using a morphological approach, i.e. measuring erosion or deposition volumes over a certain period $[7,9,12,13]$. This approach can be also used to test bedload formulas over long temporal and large spatial scales [2, 12, 17]. Recently, Pelpola and Hickin [18] estimated the volumetric expansion of a small delta into a lake using sequential aerial photography, bathymetry, and ground-penetrating radar surveys over a period of 52-year, confirming the efficiency of the morphological approach for determining longterm bed load transport rates.

The aim of the present work is to present the results of a morphologically based quantification of bedload transport in a small Spanish stream (Arroyo del Partido) where a channel rectification caused the formation of a sedimentation fan into a protected marsh. The paper also presents the restoration project carried out along the most impacted reach of the stream in order to reduce the fan growing and to improve the overall functionality of the stream.

\section{Study site and its recent record of human impacts}

The Arroyo del Partido is a low gradient basin located in Southwest Spain (Andalucia region, Huelva province). For its last $6 \mathrm{~km}$, the stream crosses the Natural Park of Doñana (UNESCO heritage site since 1994), finally discharging into Doñana marsh inside the National Park (Fig. 1). The maximum and minimum heights of the basin are 121 and $5 \mathrm{~m}$ a.s.l. respectively, and the surface area is of $308 \mathrm{Km}^{2}$. In its lower portion, the slope of the channel does not 


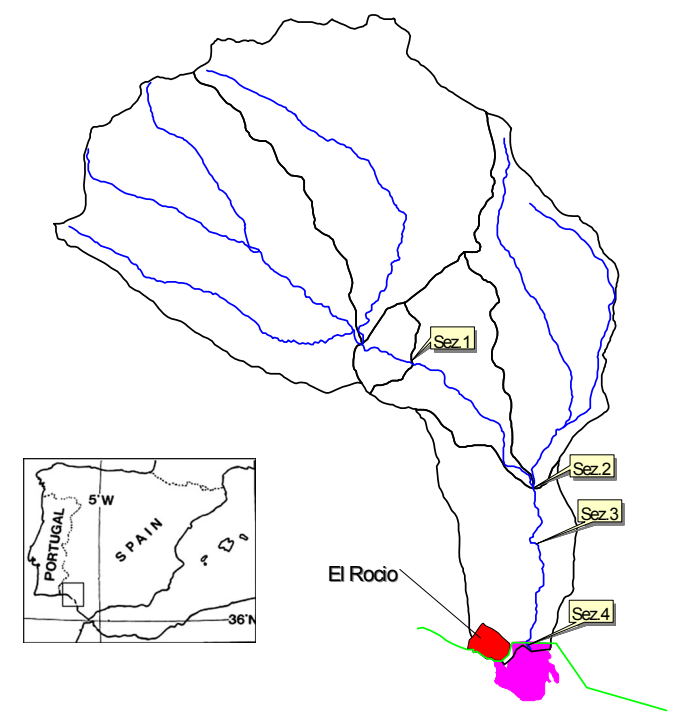

Figure 1: Location and map of the Arroyo del Partido basin and sub-basins. In 1981 the stream was chanalized from section 2 to section 4.

exceed $1 \%[14,15]$, and the channel bed and floodplains are essentially characterized by a fine and nearly homogeneous sand $\left(D_{50}=3 \mathrm{~mm} ; D_{84}=6 \mathrm{~mm}\right)$.

Even if the Donana wetland is connected to the Atlantic Ocean, the Arroyo del Partido basin is characterized by a Mediterranean-type climate. The average rainfall is about $660 \mathrm{~mm}$ per year and $80 \%$ of precipitations occur from October to March. Intense rainfalls up to $60 \mathrm{~mm}$ per day are common and characterize the torrential regime of the Arroyo del Partido stream.

Until 1980, the lower portion of the Arroyo del Partido used to flood in a wide floodplain area (up to $1 \mathrm{~km}$ ) before reaching the Doñana marsh (Fig. 2). Within this floodplain area (3700 ha) the stream was free to create avulsions and meanders as well as depositing sediments. Abandoned channels in the floodplain suggest that the original Arroyo del Partido had irregular cross section up to 10 $\mathrm{m}$ wide, $2 \mathrm{~m}$ deep and had a slope of about $0,165 \%$.

In 1981 the lower $8 \mathrm{~km}$ long reach was rectified in order to cultivate the original sandy floodplain (Fig. 2), which was levelled and converted into arable land. The channel was that narrow $(15 \mathrm{~m})$ that early ' 80 flood events caused a severe incision of the channel and removed most of the embankments. In $1985 \mathrm{a}$ wider channel $(50 \mathrm{~m})$ was built. Following floods (especially the 1995-1998 winter events) seriously affected the channel embankments because of erosion of both stream banks and bed. As a consequence of the increased sediment transport, a sedimentation fan was produced at the closing section (see Results), which correspond to the Doñana marsh very near the El Rocio village. An attempt of stabilizing the bed by building a regular meandering channel within a $100 \mathrm{~m}$ wide floodplain (Fig. 2) unsurprisingly failed because of repeated massive sedimentation of the whole structure. 

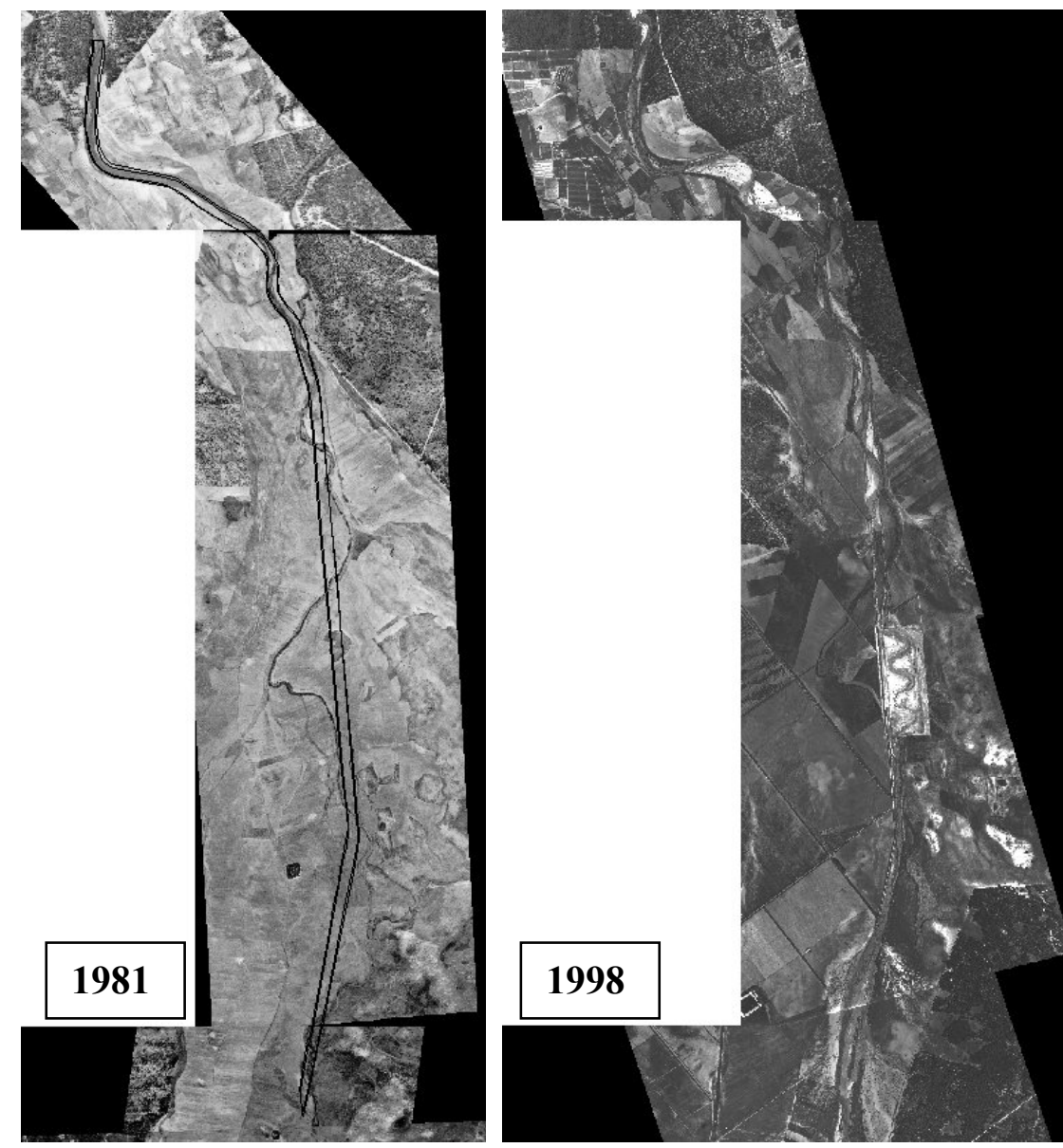

Figure 2: The lower reach of the Arroyo del Partido in its quasi-natural conditions as appeared in an aerial photo from 1956 (photo on the left). The black lines define the borders of the channel built in 1981. The rectification caused severe bank erosion, which resulted in overflows and abundant sediment deposition on the floodplain (photo on the right).

\section{Methods}

The planform expansion of the sedimentation fan was determined by comparing aerial photographs of the fan taken at certain intervals. Eleven aerial photographs of the lower portion of the Arroyo del Partido stream and of its fan (Fig. 3) were obtained or specifically committed (1954, 1982, 1985, 1993, 1996, 1997, 1998, 2000, 2001, 2001 and 2003). 

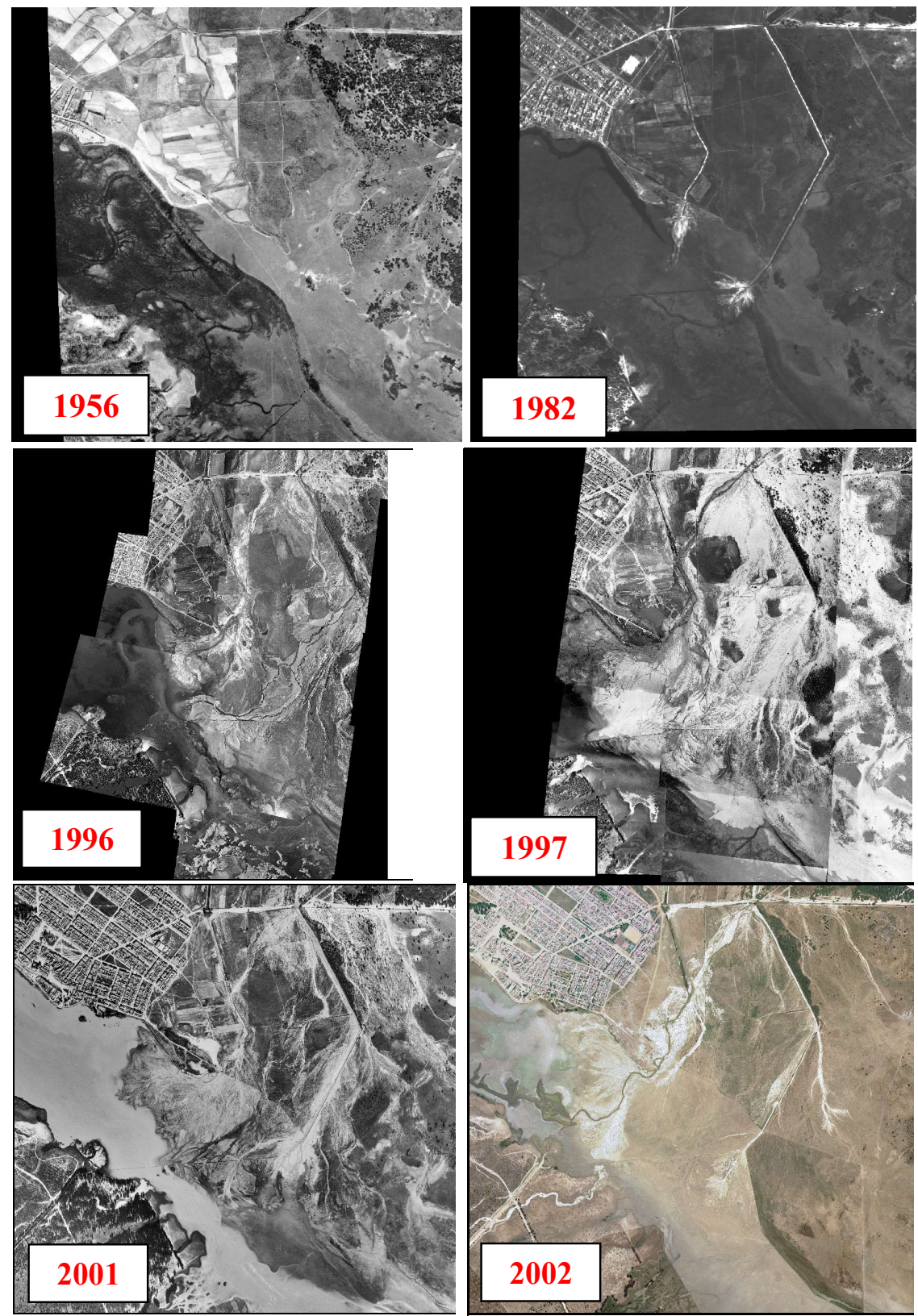

Figure 3: Successive aerial photographs of the Arroyo del Partido sedimentation fan within the Doñana marsh. The lower portion of the channel rectification is clearly visible in the 1982 photo, as well as the incipient accumulation of transported sand at its downstream end. The sedimentation fan experienced a formidable planform increase in the late $1990 \mathrm{~s}$. 
The aerial photographic prints have been scanned at a resolution of 300 to $600 \mathrm{dpi}$ in order to obtain an average pixel dimension of less than $2 \mathrm{~m}$ depending on the scale of the photos. The aerial photographs have then been geocorrected and co-registered at a common mapping base at 1:10000 scale. A minimum of 10 clearly visible control points have been used to warp single images. Second order polynomial transformations have been then applied, obtaining root mean square errors (RMSE) always less than $5 \mathrm{~m}$. The margin of the sedimentation fan was digitized on each aerial photograph (using Arc View v. 3.2) and was identified due to the distinct colour changes between the sediment of the fan and the vegetation of the marsh. The aerial photographs were always taken in summertime.

A discharge gauging station built on the middle portion of the canalized reach of the Arroyo del Partido have continuously suffered from sedimentations and provided just few isolated values. This have been used to calibrate the application of an hydrological model (HEC-HMS v.2.1.3.) to generate continuous discharge from continuous hourly precipitation records collected in a raingauge station located within the basin $[11,15]$.

\section{Expansion of the sedimentation fan over the Doñana marsh}

The margins of the sedimentation fan were digitized on aerial photographs and were used to calculate the fan areas and expansion between two successive analyzed years (Fig. 4). As to the quantification of the volumetric increase of the fan into the Doñana marsh, three topographical surveys were carried out in summer 1997, 1998 and 2003. A total station was used on the first two surveys, whereas a differential GPS device was used in the later. The acquired topographic data allowed the calculation of digital elevation models of the whole area for the mentioned three years. To reconstruct the digital elevation model of the area before the canalization, a series of core samplings were taken during the 1997 topographical survey and allowed the estimation of the depth of deposited sand over the clayey marsh surface. This allowed a reasonable estimation of the volume of the sediments deposited over the Doñana marsh in $1997 \approx 2.5 \times 10^{6}$ $\left.\mathrm{m}^{3}\right), 1998\left(\approx 3.7 \times 10^{6} \mathrm{~m}^{3}\right)$, and $2003\left(\approx 4.4 \times 10^{6} \mathrm{~m}^{3}\right)$.

The volumetric annual expansion of the fan was then estimated assuming a linear relation between the aerial and the volumetric expansion of the sedimentation cone. The results show that the fan virtually appeared only in 1993, thus more than a decade after the channel rectification (Fig. 5). Even if in this period a series of high magnitude floods occurred, these affected the upper canalized portion of the stream (channel erosion, banks removal, and sedimentation on the floodplains) without causing substantial amount of sediments reaching the Doñana marsh. In fact, during this first phase (1981$1993)$ the annual transport rate was very low $\left(2.1 \times 10^{3} \mathrm{~m}^{3}\right.$ per year). Soon after that, the sedimentation cone experienced a dramatic expansion and reached a volume of a $3.7 \times 10^{6} \mathrm{~m}^{3}$ by 1998 , at a rate of $7.4 \times 10^{5} \mathrm{~m}^{3}$ per year from 1993 to 1998 (Fig. 5). The highest transport rate was registered between 1996 and 1997, 


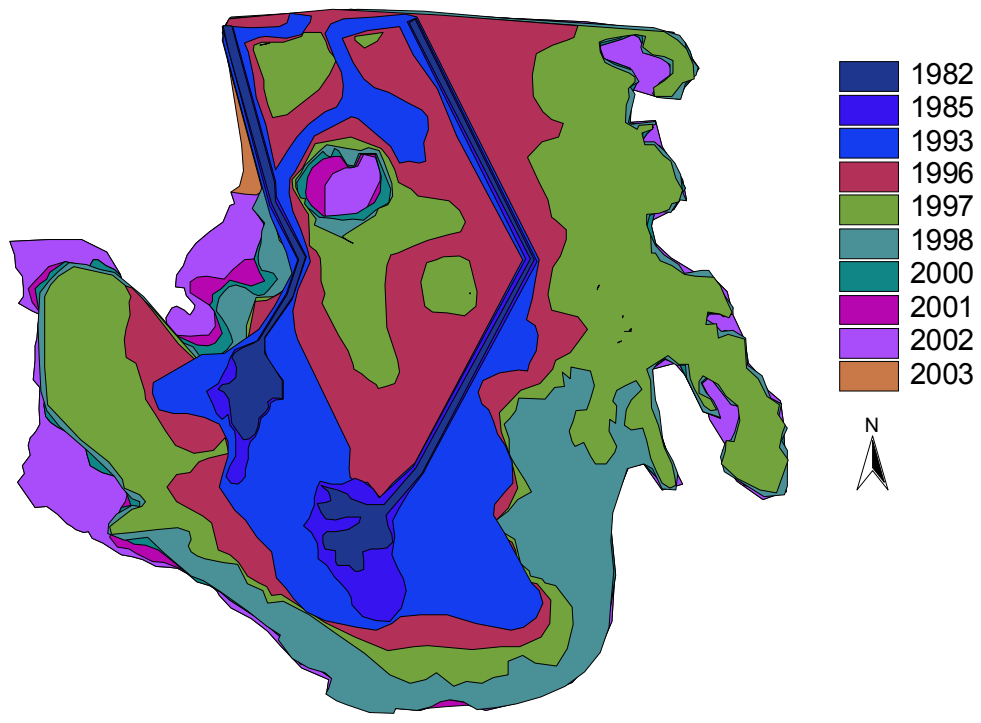

Figure 4: Planimetric expansion of the Arroyo del Partido fan on the Doñana marsh from 1982 to 2003 . The upper border corresponds to a road path with fords reaching the El Rocio Village.

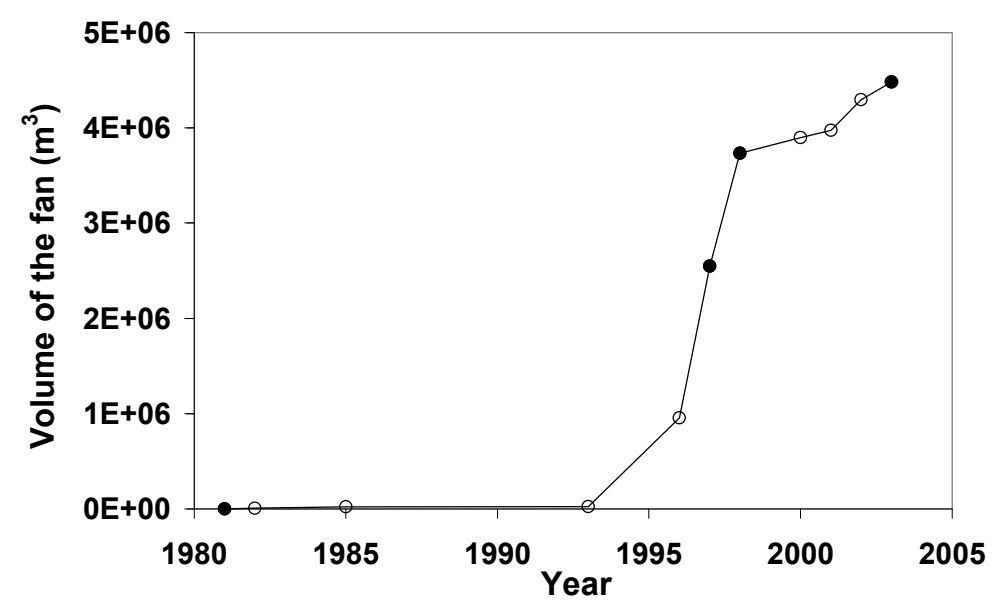

Figure 5: Volumetric increase of the Arroyo del Partido fan. The solid circles represent actual volumes measured in the field, whereas the empty ones represent the values obtained from the planimetric expansion of the fan. 
with a transport rate up to $1.6 \times 10^{6} \mathrm{~m}^{3}$ per year. After 1998 the expansion rate decreased substantially stabilizing around $1.5 \times 10^{5} \mathrm{~m}^{3}$ per year from 1998 to 2003.

The variability associated with average annual bedload rate is partially due to the occurrence and nature of flood events. In fact, 1996, 1997, and 1998 (when the fan experienced the fastest volumetric expansion) where characterized by the higher number of bedload transport events, and by the occurrence of the higher magnitude flood $\left(277 \mathrm{~m}^{3} \mathrm{~s}^{-1}\right)$. However, the following decrease of bedload transport can be also ascribed to morphological changes experienced by the channel bed which reduced its transport capacity. The average channel slope, which was around $0.165 \%$ before the canalization, was still as steep as $0.2 \%$ during 1999 and reduced to $0.157 \%$ in 2003 . This is likely due to the progressive expansion of the sedimentation fan and to an increased tendency of meandering. Moreover, by 1998 most of the artificial levees were eroded, and the overbankfull flows were able to flood and deposit sand on the adjacent floodplains. Considering the shape of cross-sections measured from 1981 to 2003, it has been estimated that, relative to the pre-canalization conditions, the bankfull discharge (recurrence interval 1.2 years) flowed with a shear stress six times higher just after the canalization. Due to later self-established cross section geometry with increased channel width, by 2003 the bankfull shear stress would have been lower, i.e. four times higher than in the pre-1981 conditions [11].

Overall, the combined effects of the reduced shear stress in the channel and the progressive stabilization of channel bars and banks by vegetation has progressively reduced the sediment availability, thus decreasing sediment transport from 1993 to 2003.

\section{Restoration of the sedimentation fan}

The assessment of the annual bedload transport amount and dynamics from 1981 to 2003 was functional to the definition of a management and restoration strategy for the Arroyo del Partido sedimentation fan. This need was driven by the fact that the Doñana National Park (classified as RAMSAR and UNESCO world heritage site) represents the main protected area in Spain. The overall objective of the restoration of the Arroyo del Partido was to detain its fan from growing more deeply into the Doñana marsh and to recover abandoned farming lands to provide menaced Imperial eagle and Iberian lynx populations with a suitable hunting ground [20].

In order to detain the growing fan and to restore the portion of canalized stream, Mintegui et al. [14] proposed to remove one of the banks and to return an area of 1500 ha to the stream as a natural floodplain. The aim was to facilitate the undergoing tendency of the main channel to widen and reduce its slope and shear stress during floods by favouring overbank flowing and sand deposition on the floodplain. This would have led to a high degree of freedom for the stream to wander, meander and create avulsions within the floodplain, as well as stopping the fan expanding into the Doñana marsh. The restoration plan was implemented in 2006 with the removal of some remaining portions of banks and with the built 
of a transversal bed sill at the upstream end of the original canalized portion of the stream in order to stabilize the bed and prevent bed incisions. The restoration plan is monitored continuously in both the hydraulic [16] and the vegetation selfreestablishment point of view [3].

\section{Conclusions}

The paper present an application of the morphological approach for the quantification of bedload transport rate at the annual scale, and demonstrates the utility of combining sequential aerial photography and topographical surveys to reconstruct the planimetric and volumetric expansion of a sedimentation fan. The applied method is relatively inexpensive and easy to use if compared with direct or indirect field devices for the bedload monitoring. Even if the transport rate can be only be assessed at the annual scale, the method allows avoiding errors associated with bedload field survey during high flows and to exclude the influence of short-term fluctuation of bedload $[5,8]$ in the sediment transport calculation. The method is thus a viable alternative to direct monitoring for assessing the long-term bedload rates in similar conditions worldwide. A similar approach, together with the contemporary use of bathymetry and groundpenetrating radar, has proved to allow the quantification of bedload rates in a partially submerged delta [18].

The annual bedload transport rate ranged from $3.7 \times 10^{6}$ to $2.1 \times 10^{3} \mathrm{~m}^{3}$ per year between 1982 and 2003, and this remarkable variability have been mainly related to the changing geometrical conditions of the main channel. For a few years after the canalization (1981-1993) the stream eroded locally banks and margins, depositing sediments in the overflow areas and carrying little amount of sediments at its downstream end. In a following phase (1993-1998), characterized by a considerable number of high magnitude floods, a substantial amount of sediments reached the Doñana marsh and created a much extended fan $\left(3.8 \times 10^{6} \mathrm{~m}^{2}\right)$. During this period, the sequence of floods progressively favoured the self-establishment of cross-sections and the channel slope adjustment such that over the following years (1998-2003) the fan reduced its expansion rate.

The overall assessment of sediment transport and the evidence that a free wandering channel within a defined floodplain reduced the volumetric expansion of the fan has driven the choice of the restoration strategy for the Arroyo del Partido. The restoration plan, implemented from 2006, entail the removal of an entire artificial bank and make "room" for the river within a protected floodplain area set aside from cropping, where the flow will deposit sediments and possibly create secondary channels.

\section{Acknowledgements}

We would like to thank the Scientific Commission of the Project Doñana 2005 and the Conservation Area Manager of the Doñana National Park for their support. The paper has been written while LM was supported by a Marie-Curie fellowship (EU $7^{\text {th }}$ Framework Programme; PIEF-GA-2008-219294). 


\section{References}

[1] Bunte, K., Abt, S.R., Effect of sampling time on measured gravel bed load transport rates in a coarse-bedded stream. Water Resources Research, 41, W11405, doi:10.1029/2004WR003880, 2005.

[2] Carson, M.A., Griffiths, G.A., Bedload transport in gravel-bed channels, Journal of Hydrology (New Zealand), 26(1), pp. 1-15, 1987.

[3] Garcia-Novo, F., Escudero Garcia, J.C., Carotenuto, L., Garcia Sevilla, D., Fernandez Lo Faso, R.P., The restoration of El Partido stream watershed (Doñana Natural Park). A multiscale, interdisciplinary approach. Ecological Engineering, 30, pp. 122-130, 2007.

[4] Gomez, B., The potential rate of bed-load transport. Proceedings of the National Academy of Sciences of the United States of America, 103(46), pp. 17170-17173, 2006.

[5] Gomez, B., Richard, L.N., Hubbell, D.W., Temporal variations in bedload transport rates associated with the migration of bedforms. Earth Surface Processes and Landforms, 14, 135-156, doi:10.1002/esp. 3290140205, 1989.

[6] Gomez, B., Bedload transport. Earth-Science Reviews, 31, pp. 89-132, 1991.

[7] Ham, D., Church, M., Bed-material transport estimated from channel morphodynamics: Chilliwack River, British Columbia. Earth Surface Processes and Landforms, 25, pp. 1123-1142, 2000.

[8] Hoey, T.B., Temporal variations in bedload transport rates and sediment storage in gravel-bed rivers, Progress in Physical Geography, 16, pp. 319338, doi:10.1177/030913339201600303, 1992.

[9] Lane, S.N., Richards, K.S., Chandler, J.H., Morphological estimation of the time-integrated bed load transport rate. Water Resources Research, 31, pp. 761-772, 1995.

[10] Laronne, J.B., Alexandrov, Y., Bergman, N., Cohen, H., Garcia, C., Habersack, H., Powell, D.M., Reid, I., The continuous monitoring of bed load flux in various fluvial environments. In Erosion and Sediment Transport Measurement in Rivers: Technological and Methodological Advances, eds. Bogen, J., Fergus, T., Walling, D.E. IAHS Publication 283, International Association of Hydrological Sciences: Wallingford, pp. 134$145,2003$.

[11] Mao, L., Analisi comparativa del trasporto solido di corsi torrentizi in diversi ambiti geografici. Ph.D. Thesis, University of Padova, Italy, 2004.

[12] Martin, Y., Evaluation of bed load transport formulae using field evidence from the Vedder River, British Columbia. Geomorphology, 53, pp. 75-95, 2003.

[13] McLean, D.G., Church, M., Sediment transport along lower Fraser River 2. Estimates based on the long-term gravel budget. Water Resources Research, 35, 2549-2559, 1999.

[14] Mintegui J.A., Robredo J.C., Sendra P.J. Avenidas torrenciales en el Arroyo del Partido y su incidencia en la marisma del Parque Nacional de 
Doñana. Naturaleza y Parques Nacionales, Serie Técnica, Organismo Autónomo Parques Nacionales, Madrid, pp. 373, 2003.

[15] Mintegui, J.A, Lenzi, M.A., Robredo, J.C, Mao L., Movilización versus estabilización de los sedimentos en los cursos sometidos a la dinámica torrencial. Organismo Autónomo Parques Nacionales, Ministerio de Medio Ambiente, Serie Técnica, Madrid, pp. 143, 2006.

[16] Mintegui, J.A, Robredo, J.C, De Gonzalo Aranoa, C., Huelin Rueda, P. Restoration of a degraded torrential stream by means of flood control system: the case of Arroyo del Partido stream (Spain). Proceedings Debris Flow conference 2010, this issue.

[17] Nicholas, A., Modelling bedload yield in braided gravel rivers. Geomorphology, 36, 89-106, 2000.

[18] Pelpola, C.P., Hickin, E.J., Long-term bed load transport rate based on aerial-photo and ground penetrating radar surveys of fan-delta growth, Coast Mountains, British Columbia. Geomorphology, 57(3-4) pp. 169-181, 2004.

[19] Rickenmann, D., McArdell, B.W., Continuous measurement of sediment transport in the Erlenbach stream using piezoelectric bedload impact sensors. Earth Surface Processes and Landforms, 32, pp. 1362-1378, 2007.

[20] Saura Martinez, J., Bayan Jardin, B., Casas Grandes, J., Ruiz deLarramendi, A., Urdiales Alonso, C., Documento Marco para el Desarrollo del Proyecto Doñana 2005. Ministerio de Medio Ambiente, Madrid, pp. 201, 2001. 